\title{
19. ROCK-MAGNETIC PROPERTIES OF PLEISTOCENE PASSIVE MARGIN SEDIMENTS: ENVIRONMENTAL CHANGE AND DIAGENESIS OFFSHORE NEW JERSEY ${ }^{1}$
}

\author{
Michael Urbat ${ }^{2}$
}

\begin{abstract}
Downhole changes in the concentration, grain size, and mineralogy of the magnetic components of Holocene through upper Pleistocene continental slope sediments (Ocean Drilling Program Holes 903A and 904A) were analyzed to judge the primary detrital vs. the diagenetic origin of the magnetic signal. Natural remanent magnetization (NRM), magnetic susceptibility ( $\kappa$ ), anhysteretic remanent magnetization (ARM), isothermal remanent magnetization (IRM), and additional hysteresis measurements were performed for densely sampled intervals (ca. every $15 \mathrm{~cm}$ ). Single-domain through small pseudosingle-domain magnetite is identified as the dominant remanence carrying mineral. However, relative changes of the rock-magnetic properties on a sample-by-sample basis appear to be more instructive in detecting diagenetic overprints of the signal than are determinations of absolute grain sizes. Major downhole changes in the rock-magnetic properties are dominated by the original detrital signal and clearly record differences of glacial and interglacial modes of deposition. Postdepositional dissolution and the authigenic growth of magnetite modulate the detrital magnetic mineralogy dominantly in well-defined sections, which represent the contact of unconformably deposited sediment packages. This diagenetic alteration of the magnetic signal is restricted to the finer ferrimagnetic fraction and can be detected by analyzing the grain selectivity of the ARM acquisition process. The alteration of the magnetic mineralogy occurred repeatedly during sediment diagenesis.
\end{abstract}

\section{INTRODUCTION}

Rock-magnetic and environmental magnetic methodology is increasingly applied to a wide array of scientific disciplines including climatology, paleoceanography, sedimentology, and soil science (Verosub and Roberts, 1995). Rock-magnetic techniques are sensitive, generally nondestructive, relatively rapid, and inexpensive. Thus, high-precision and high-resolution data sets can be obtained. Magnetic minerals in sediments accurately mirror diverse aspects of changes in the depositional environment. Most of the applications of environmental magnetism assume that a primary detrital magnetic signal is analyzed. This assumption is generally supported by correlating rock-magnetic parameters to more established sedimentological or geochemical parameters (e.g., Chave and Denham, 1979; Kent, 1982; Shackleton et al., 1984; Robinson, 1986; Bloemendal and DeMenocal, 1989; DeMenocal et al., 1991; Thouveny et al., 1994).

Several studies, however, revealed that postdepositional, biogeochemical processes associated with reductive diagenesis (degradation of organic matter; e.g., Froehlich et al., 1984) may severely modify the magnetic signal. The primary magnetic signal was shown to have been significantly altered throughout the sediment column to several tens of meters below the sediment/water interface, primarily as a function of (abrupt) changes in the depositional environment (e.g., Bloemendal et al., 1988, 1992; Karlin and Levi, 1983; Karlin, 1990a, 1990b; Leslie et al., 1990a, 1990b; van Os, 1994; Urbat, 1995). The bacterially mediated reduction (e.g., Schinzel et al., 1993) and $\mathrm{H}_{2} \mathrm{~S}$ as the dissolving agent (Canfield and Berner, 1987) control the dissolution of iron oxides (Anderson and Rippey, 1988; Leslie et al., 1990b; Oldfield et al., 1992; Bloemendal et al., 1993). This process is often accompanied by a subsequent conversion of magnetite by way of greigite into nonmagnetic pyrite (Karlin and Levi, 1983, 1985). Greigite may be preserved if pyritization does not go into

'Mountain, G.S., Miller, K.G., Blum, P., Poag, C.W., and Twichell, D.C. (Eds.), 1996. Proc. ODP, Sci. Results, 150: College Station, TX (Ocean Drilling Program).

${ }^{2}$ Geologisches Institut, Universität zu Köln, Zülpicher Strasse 49A, 50674 Köln, Federal Republic of Germany. urbat@geocip.geo.uni.koeln.de completion (e.g., Roberts and Turner, 1993; Reynolds et al., 1994). The authigenic growth of new iron oxides and iron sulfides can occur either (1) abiotically (Maher and Taylor, 1988) or (2) microbially mediated by way of magnetotactic bacteria producing intracellular magnetite (e.g., Petersen et al., 1986; Stolz et al., 1986, 1990; Vali and Kirchvink, 1989) or greigite (Mann et al., 1990; Bazylinski et al., 1993) or (3) by way of dissimilatory bacteria producing extracellular magnetite (Lovley and Phillips, 1988).

The loss of the primary magnetic signal may compromise any study focusing on the paleo-intensity of the Earth's magnetic field (e.g., Tauxe and Shackleton, 1994; Roberts et al., 1994), magnetostratigraphy (e.g., Musgrave et al., 1993; van Hoof et al., 1992), or rock magnetic-paleoceanographic linkages that result indirectly from a climatic control of the detrital magnetic input in the sediments.

In this rock-magnetic study, the effects and the extent of reductive diagenesis on the magnetic mineralogy of Holocene through Pleistocene sediments from Holes 903A and 904A are investigated. The major objective is to evaluate the detrital vs. diagenetic nature of the magnetic signal of the sediments. The effects of abrupt changes in the depositional environment on the rock-magnetic properties could be effectively analyzed in a sediment that is potentially affected by mass-flow or turbidite sedimentation. The practical questions to be answered are, if a specific (diagenetic) rock-magnetic pattern is related to sedimentary nonsteady state conditions during sediment genesis, what does it look like and is it useful to detect otherwise unrecognizable unconformities or hiatuses in the sediment column. Related studies on directional data (NRM, anisotropy of magnetic susceptibility AMS) are presented in Urbat (1995).

\section{GEOLOGICAL SETTING}

Sites 903 and 904 are located about $141 \mathrm{~km}$ east-southeast of Barnegat Inlet, New Jersey, on the modern upper continental slope in water depths of 444 and $1123 \mathrm{~m}$, respectively (Mountain, Miller, Blum, et al., 1994). The Pleistocene section of Site 903 encompasses Oxygen Isotope Stages 5.5 through 14 (Christensen et al., this volume). The hemipelagic sediments are predominantly heavily biotur- 
bated, greenish gray silty clays with very fine quartz sands. The Pleistocene section at Site 904 is comprised of homogeneous to heavily bioturbated silty clays that display pinkish gray to gray color bands, typically 50 - to $100-\mathrm{cm}$ thick. Iron monosulfides are abundant between 4.3 and $43 \mathrm{~m}$ below seafloor (mbsf) and are concentrated largely in burrows filled with silty clay and fine-grained quartz sands. Several small-scale layers contain pyrite nodules. The Pleistocene interval recovered at Site 904 comprises Oxygen Isotope Stages 5.5 through 8 (Christensen et al., this volume). The average sedimentation rates are highest at Site 903 , with several tens of $\mathrm{cm} / \mathrm{k} . \mathrm{y}$., vs. about $22 \mathrm{~cm} / \mathrm{k} . \mathrm{y}$. at Site 904 . Both sampled intervals at Holes $904 \mathrm{~A}$ and $903 \mathrm{~A}$ are within the current sulfate reduction zone. To a depth of $60 \mathrm{mbsf}$, sulfate ions are depleted by $30 \%$ at Site 904 , whereas sulfate reduction already ceases at 13 mbsf at Site 903 (Shipboard Scientific Party, 1994a, 1994b).

\section{METHODS}

Cores from the two sites were sampled by pressing oriented 6.5 $\mathrm{cm}^{3}$ standard ODP plastic boxes in the unconsolidated sediment, which were then removed using nonmagnetic spatulas: Cores 150$903 \mathrm{~A}-1 \mathrm{H}$ through $4 \mathrm{H}(=0.1-35 \mathrm{mbsf})$ and Cores $150-904 \mathrm{~A}-1 \mathrm{H}$ through $6 \mathrm{H}(0.1-56 \mathrm{mbsf})$. All cores were sampled approximately every $15-20 \mathrm{~cm}$ in intervals with no visible lithologic changes and every $5 \mathrm{~cm}$ across visible lithologic changes. The resulting $400 \mathrm{sam}-$ ples were stored refrigerated in airtight boxes to prevent drying and minimize potential magnetomineralogical changes (e.g., Oldfield, 1992).

Rock-magnetic measurements included natural remanent magnetization (NRM), anhysteretic remanent magnetization (ARM), isothermal remanent magnetization (IRM), magnetic susceptibility $(\kappa)$ for all samples (at the University of Cologne, Germany), and addi- tional hysteresis measurements for selected samples (Lamont-Doherty Earth Observatory, New York). Remanent magnetization intensities were determined on a cryogenic superconducting rock magnetometer (Gorree and Fuller, 1976) or a Molspin spinner magnetometer (Molspin Ltd., GB) with sensitivities of $5 \times 10^{-6} \mathrm{~A} / \mathrm{m}$ and $5 \times 10^{-4} \mathrm{~A} / \mathrm{m}$, respectively. Alternating-field demagnetizations were done using a 2G-Enterprises Model 600 (measured noise level within the coil $<1 \mathrm{nT}$ ).

Low-field mean susceptibilities $\kappa$ were calculated from AMS measurements (see Table 1) on a Kappabridge KLY-2. Values were corrected for the diamagnetic holder $\left(\kappa=-8.5 \times 10^{-6} \mathrm{SI}\right)$ and the plastic cube $\left(\mathrm{K}=-4.5 \times 10^{-6} \mathrm{SI}\right)$. ARM was imparted in a peak alternating field of $150 \mathrm{mT}$ and a biasing steady field $\mathrm{B}=0.05 \mathrm{mT}$. The ARM intensity of all samples was AF demagnetized to at least one step beyond the median destructive field of ARM (MDF-ARM; Table 1) thereafter. IRM-acquisition behavior was determined for selected samples by measuring the magnetization intensity after exposure of each specimen to progressively higher pulse fields $(\max =1.5 \mathrm{~T})$. All remaining samples were magnetized in a single step (IRM at $1.5 \mathrm{~T}$ $\left.\left[\mathrm{IRM}_{\varpi 1.5 \mathrm{~T}}\right]\right)$. All samples were subjected to an incrementally increasing reversed field IRM (maximum applied field $=300 \mathrm{mT}$; see Table 1). In addition, IRM $M_{\Theta 1.5 T}$ was $A F$ demagnetized to at least one step beyond the median destructive field of IRM (MDF-IRM; Table 1). Hysteresis measurements were carried out on selected samples from Hole 904A on a Princeton Measurements Corp. MicroMag, Model 2900 Alternating Gradient Force Magnetometer. The applied peak field was 1.0 Tesla (8-mT field increments).

Both hysteresis properties $H_{c}$ (coercive force) and $M_{s s} / M_{s}$ (remanent saturation magnetization/saturation magnetization) are strongly grain-size dependent for hydrothermally grown magnetite (Heider et al., 1987). $H_{c}$ and $M_{r s} / M_{s}$ of these synthetic magnetites follow a power law dependence on nominal grain-size $d\left(\mathrm{H}_{c} \alpha d^{0.59 \pm 0.06} \mathrm{M}_{\mathrm{s}} / \mathrm{M}_{\mathrm{s}} \alpha\right.$ $d^{-0.59 \pm 0.06}$ over 4.5 decades of $d$ ). To judge whether the rock-magnetic

Table 1. Frequently used symbols and their descriptions.

\begin{tabular}{|c|c|c|c|}
\hline Symbol & Meaning & Unit (SI) & Definition \\
\hline $\mathrm{NRM}_{@ 9 \mathrm{mT}}$ & $\begin{array}{l}\text { natural remanent magnetization, } \mathrm{AF} \text { de- } \\
\text { magnetized with } 9 \mathrm{mT}\end{array}$ & $\mathrm{A} / \mathrm{m}$ & \\
\hline MDF-NRM & median destructive field of $\mathrm{NRM}_{@ 9 \mathrm{mT}}$ & Tesla $\mathrm{T}$ & \\
\hline AMS & $\begin{array}{l}\text { anisotropy of magnetic susceptibility (Je- } \\
\text { linek 1977) }\end{array}$ & & \\
\hline$\kappa$ & low frequency susceptibility & dim.less & $\kappa=\left[\left(\kappa_{\max }+\kappa_{i n t}+\kappa_{\text {min }}\right) / 3\right] \mathrm{V}_{0} / \mathrm{V}$ \\
\hline & & & $\begin{array}{c}\text { with } \\
\kappa_{\max }, \kappa_{\text {int }}, \kappa_{\min }=\text { maximum, intermediate and } \\
\text { minimum axis of AMS-ellipsoid, orthogonal }\end{array}$ \\
\hline ARM & anhysteretic remanent magnetization & $\mathrm{A} / \mathrm{m}$ & \\
\hline MDF-ARM & median destructive field of ARM & $\mathrm{T}$ & \\
\hline KARM & anhysteretic susceptibility & & $\kappa_{\mathrm{ARM}}={ }_{\mathrm{o}}$ \\
\hline IRM & isothermal remanent magnetization & $\mathrm{A} / \mathrm{m}$ & \\
\hline MDF-IRM & median destructive field of IRM & $\mathrm{T}$ & \\
\hline $\mathrm{B}_{\mathrm{cr}}$ & remanence coercive force & $\mathrm{T}$ & \\
\hline $\mathrm{S}_{0.3 \mathrm{~T}}$ & antiferromagnetic:ferrimagnetic ratio & dim.less & $\mathrm{S}_{0.3 \mathrm{~T}}=\left[\left(I R M_{@ 0.3 T} / I R M_{@ 1.5 T}\right)+1\right] / 2$ \\
\hline
\end{tabular}

Notes: dim.less $=$ dimensionless. $\mathrm{SI}=$ Systeme International d'Unites. 
properties of the New Jersey slope samples are comparable to hydrothermally grown magnetite, the two power laws were linked by way of grain-size $d$ in a linear equation, using the proportionality factors $3.83\left(\mathrm{H}_{\mathrm{c}}\right)$ and 0.039 for $\mathrm{M}_{\mathrm{rs}} / \mathrm{M}_{\mathrm{s}}$ (cf. Karlin, 1990a, 1990b). Thus, a regression line is obtained for the synthetic magnetites. If the regression of the investigated samples indicates that their hysteresis properties are statistically indistinguishable from those of the hydrothermally grown magnetite, the nominal grain size, $d$, can be calculated for magnetite contained in the sampled sediments. However, the linear regression lines calculated using Heider et al.'s (1987) power laws yield a physically nonsensical nonzero intercept of $H_{c}$ or $M_{r s} / M_{s}$ for grains, at least in the larger PSD through MD size ranges. Therefore, such grain sizes cannot be determined by the method used here.

Additional high-field susceptibility ( $\chi \mathrm{hf})$ measurements on six samples (representative of magnetic subunits at Hole 904A) were performed on a Princeton Applied Research Vibrating Sample Magnetometer at the Institute for Rock Magnetism, University of Minnesota.

\section{RESULTS}

\section{Hole 904A}

IRM-acquisition curves representative of the sampled section at Hole $904 \mathrm{~A}$ indicate magnetite (Fig. 1). At fields of $0.5 \mathrm{~T}$ a $95 \%$ saturation of the IRM $\mathrm{I} \perp .5 \mathrm{~T}_{\text {is }}$ typically achieved. The ferrimagnetic dominance of the IRM-acquisition process is confirmed by data from the reverse field experiments (Fig. 1). Values of $\mathrm{S}_{0.3 \mathrm{~T}}$ (Table 1) are dominantly well above 0.9 . A probable contribution of $>50 \%$ from a high coercivity mineral such as hematite to the magnetomineralogy is suggested by comparison to data compiled by Bloemendal et al. (1992, their fig. 4). The coercive force $\mathrm{H}_{\mathrm{c}}$ varies linearly with $\mathrm{M}_{\mathrm{rs}} / \mathrm{M}_{\mathrm{s}}$ at Hole $904 \mathrm{~A}$ (Fig. 2). Calculated magnetite grain sizes range from 0.06 to $0.9 \mu \mathrm{m}$ (i.e., single-domain [SD] through small pseudosingle-domain [PSD] magnetite) in the sampled interval. This suggests that neither superparamagnetic nor multidomain (MD) magnetite dominates the magnetization in the Pleistocene section at Hole 904A. However, the calculated grain sizes do not account for a grain-size distribution of magnetic minerals and thus may only indicate a general grain-size tendency.

The bulk of the samples are closely grouped in the SD through ESD (elongated single-domain) region of an IRM/ $/$ vs. $B_{\mathrm{cr}}$ diagram (Fig. 3), which suggests slightly coarser magnetite than calculated from the hysteresis properties. A further-depth related-analysis of $\mathrm{IRM} / \kappa$ vs. $B_{\mathrm{cr}}$ yields a clear separation of four major magnetic zones (I through IV), despite the relatively narrow grain-size distribution of the ferrimagnetic minerals (Fig. 3). Zones I through IV are separated as follows:

Zone I encompasses the upper $17.8 \mathrm{~m}$ as well as the bottom part of the profile (52.3-56.15 mbsf). Samples from Zone I are located in the SD region. Zone II samples (17.8-37.8 mbsf) are closely grouped in between the SD and ESD-area of the diagram and display a slightly finer grain-size tendency of magnetite. Zone III is assigned to two intervals (37.8-43 and 50.92-52.01 mbsf) with magnetization intensities transitional to the low-intensity Zone IV (43-50.76 mbsf). Samples from Zones III and IV reveal an increasingly higher contribution of (super)paramagnetic minerals to susceptibility, whereas the average $\mathrm{SD}$ size range of the ferrimagnetic minerals is maintained.

A significant correlation of $\mathrm{ARM}$ and $\mathrm{IRM}_{\Theta 1.5 \mathrm{~T}}$ only exists if Zone I samples (ARM intensities $>50 \mathrm{~mA} / \mathrm{m}$ ) are excluded (Fig. 4). This different rock-magnetic behavior of Zone I samples is a result of the ARM acquisition process. ARM is grain-size selective and grains with low coercivity (MD grains) were obviously not fully magnetized with the applied direct field (i.e., not to the same relative amount that they contribute to the IRM ${ }_{\odot 1.5 T}$ ). The MDF-IRM in Zone I (Fig. 5) is markedly lower (about $20 \mathrm{mT}$ ) than is the MDF-ARM (about $40 \mathrm{mT}$ ),

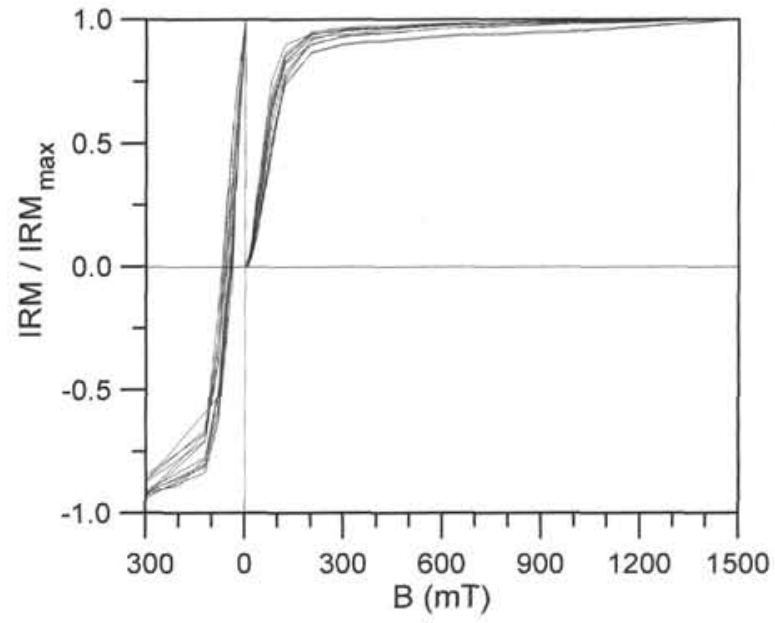

Figure 1. IRM-acquisition curves of selected samples from Cores 150-904A$1 \mathrm{H}$ through $6 \mathrm{H}$, normalized by maximum intensity (right side). Normalized intensity upon exposure to reversed field is shown on the left side.

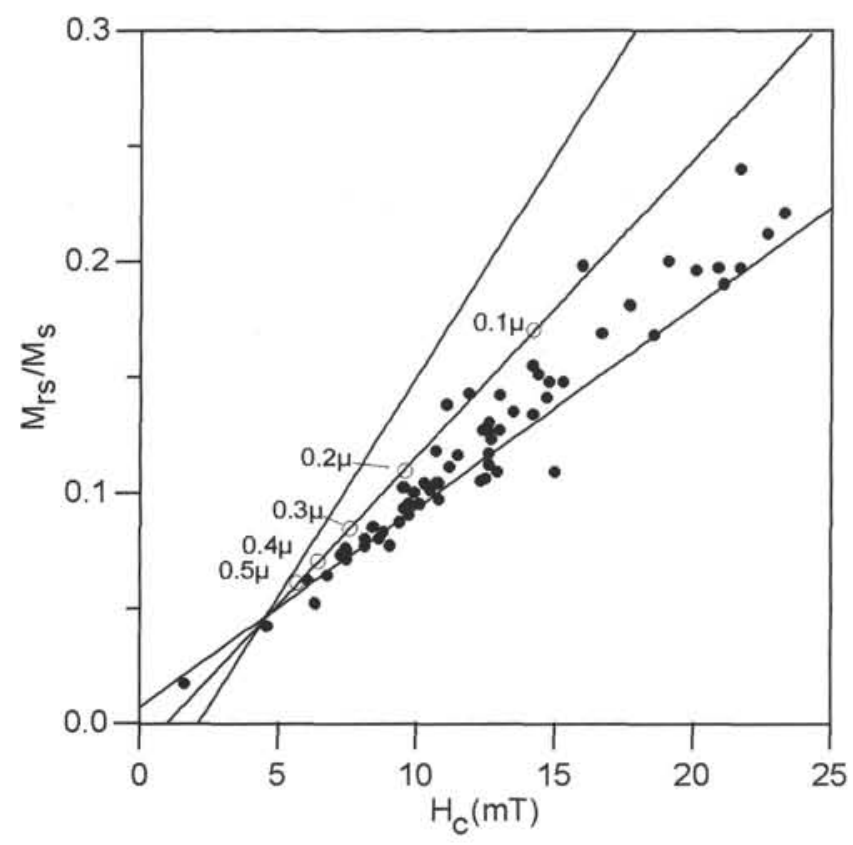

Figure 2. Hysteresis parameters $M_{r s} / M_{s}$ vs. $H_{c}$ of samples from Hole $904 \mathrm{~A}$ (solid circles). Solid lines represent experimental results obtained from hydrothermally grown magnetite by Heider et al. (1987). Open circles on middle line $\left(\mathrm{M}_{\mathrm{r}} / \mathrm{M}_{\mathrm{s}}=0.01284 \times \mathrm{H}_{\mathrm{c}}-0.0129\right)$ mark the corresponding grain diameters. Upper line $\left(\mathrm{M}_{\mathrm{s}} / \mathrm{M}_{\mathrm{s}}=0.0190 \times \mathrm{H}_{\mathrm{c}}-0.0404\right)$ and lower line $\left(\mathrm{M}_{\mathrm{rs}} /\right.$ $\left.M_{s}=0.0086 \times H_{c}+0.007\right)$ show the maximum deviation from $M_{s s} / M_{s} v s . H_{c}$, considering the maximum error of 0.6 of the exponent in the Heider et al. (1987) power laws.

contrasting the remainder of the sampled interval (exemplified by Zone III in Fig. 5; see also Fig. 6). The stacked normalized AF-demagnetization curve of IRM in Zone I (Fig. 5) declines linearly with increasing AF fields, with maximum effect between 2 and $14 \mathrm{mT}$, that is, it is a typical MD magnetite curve (see Bailey and Dunlop, 1983). The ARM is typically convex shaped toward the MDF (SD type), with maximum demagnetization at fields greater than $20 \mathrm{mT}$ throughout the interval. In Zones II-IV, the IRM demagnetization 


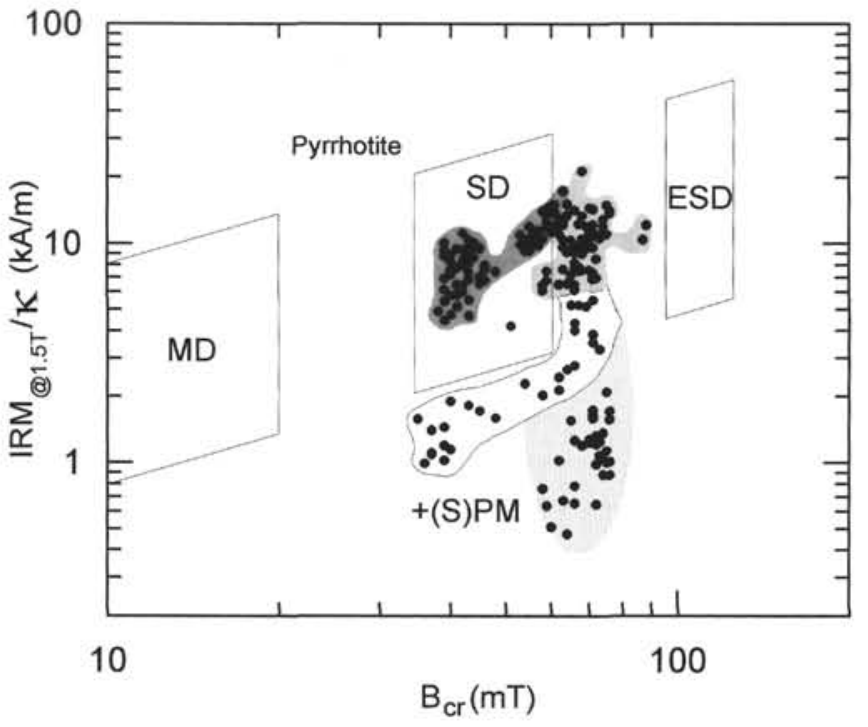

ZONE I $\quad 0.1-17.8 \mathrm{mbsf}$ and $52.3-56.15 \mathrm{mbsf}$

ZONE II $17.8-37.8 \mathrm{mbsf}$

ZONE III $37.8-43.0 \mathrm{mbsf}$ and $50.92-52.01 \mathrm{mbsf}$

ZONE IV $43.55-50.76 \mathrm{mbsf}$

Figure 3. Comparison of Hole 904A rock-magnetic properties with grainsize classification following Bradshaw and Thompson (1985). Shading separates Zones I through IV. Note that Zones I through IV are not strictly downhole. $\mathrm{MD}=$ multidomain magnetite, $\mathrm{SD}=$ single-domain magnetite, $\mathrm{ESD}=$ elongated $\mathrm{SD}$, and $(\mathrm{S}) \mathrm{PM}=$ (super)paramagnetic minerals.

curve resembles that of ARM, the latter of which is still slightly harder than IRM (MDF-ARM, MDF-IRM about $45 \mathrm{mT}$ ). It is obvious from these curves that the ARM emphasizes the coercivity range of $20-50 \mathrm{mT}$ in all four magnetic zones. This effect is most obvious in Zone I where ARM- and IRM-demagnetization curves markedly deviate from each other. This hypothesis is in accordance with experi-

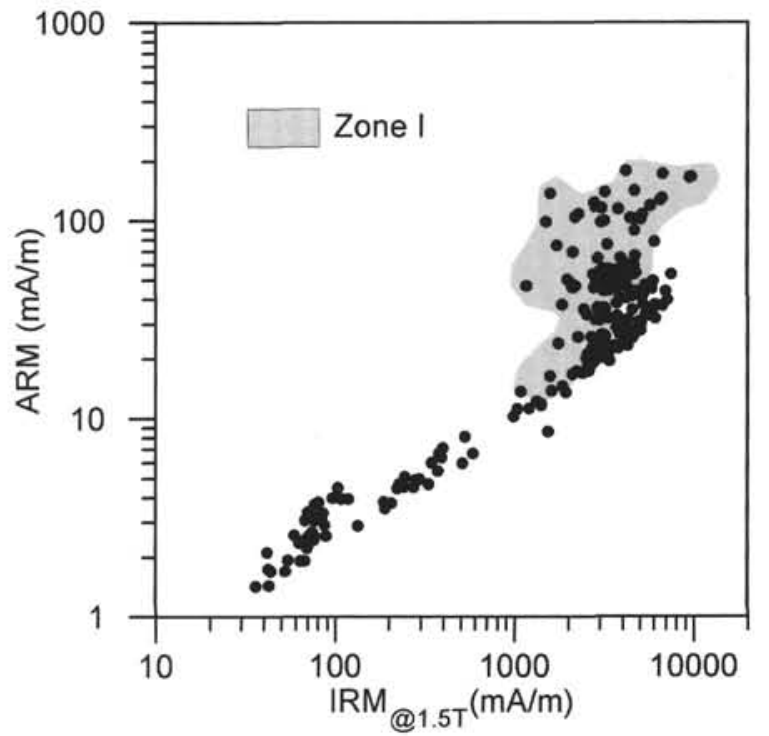

Figure 4. Double-logarithmic scatter plot of ARM vs. IRM đI.ST $_{\text {for samples }}$ from Hole 904A. Shaded area separates magnetic Zone I. Note that ARM is not linear in IRM in Zone I. $R=0.9$ for the remaining samples.

ments on synthetic samples, which indicate that fine magnetite grains are more easily magnetized anhysteretically than coarse grains (e.g., Dankers, 1978). This grain-size selectivity of the ARM acquisition process in turn is used in this study for a more detailed analysis of magnetite grain-size distribution within a single sample. Relatively increasing or decreasing concentrations of coarser and finer grains compared to the central grain-size tendency are interpreted.

Natural and laboratory induced magnetization intensities and magnetic susceptibility parallel each other in their general trends in the upper Pleistocene interval at Hole 904A (Fig. 6). Although the range of intensities of $\mathrm{NRM}_{\circledast 9 \mathrm{mT}}(<0.05-50 \mathrm{~mA} / \mathrm{m}), \mathrm{ARM}(<2-200$ $\mathrm{mA} / \mathrm{m})$ and $\operatorname{IRM}_{\Theta 1.5 \mathrm{~T}}(<0.06-20 \mathrm{~A} / \mathrm{m})$ spans more than 2 orders of magnitude, respectively, susceptibility is more restricted within the range of $100-2000 \mu \mathrm{SI}$. Zones I and II are characterized by the highest magnetization intensities, whereas Zone III is transitional to the
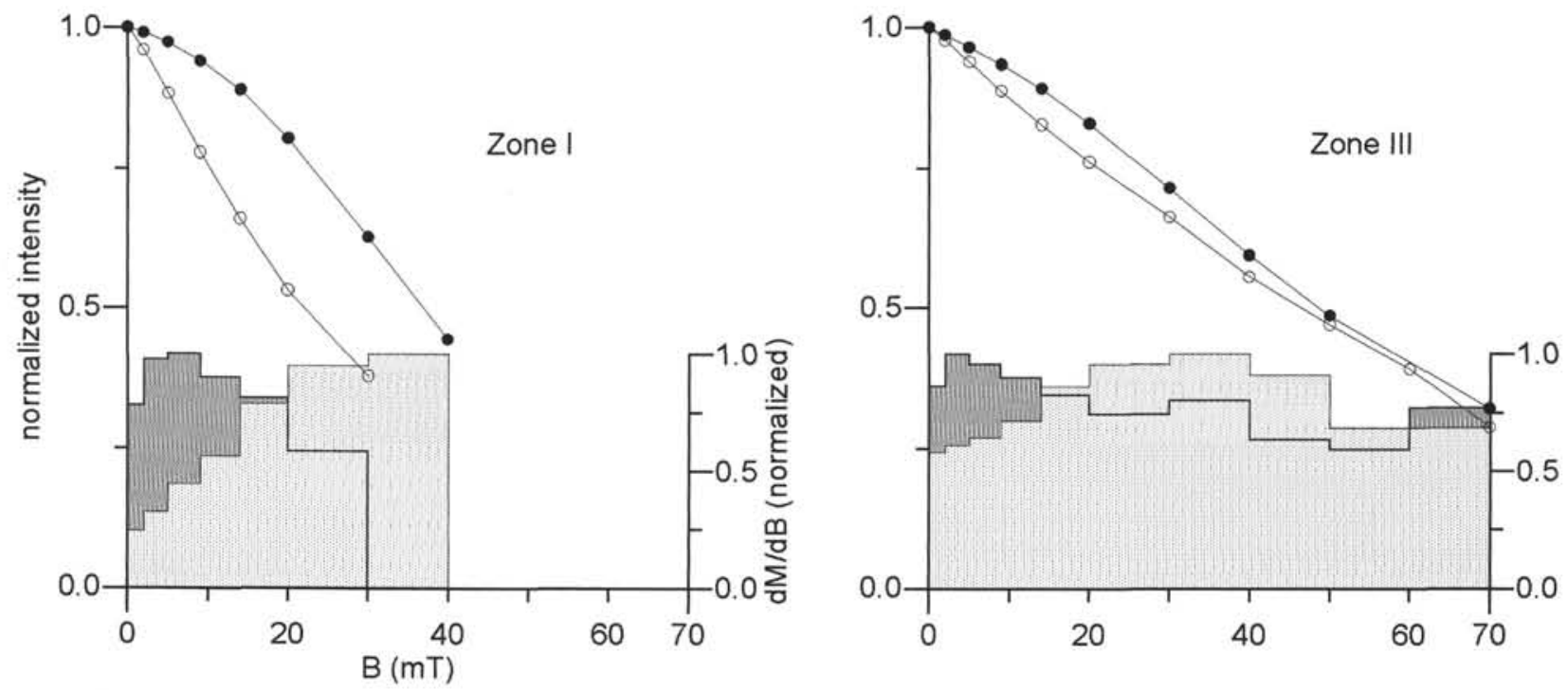

Figure 5. Stacked AF-demagnetization curves of samples from Zones I $(N=86)$ and III $(N=36)$, Hole 904A. Open circles $=$ IRM demagnetization, and solid circles = ARM demagnetization. Block diagrams represent the derived distribution over the demagnetizing alternating field trajectory $($ dark-shaded blocks = IRM, and light-shaded blocks = ARM). Zone III is representative of Zones II and IV also. 


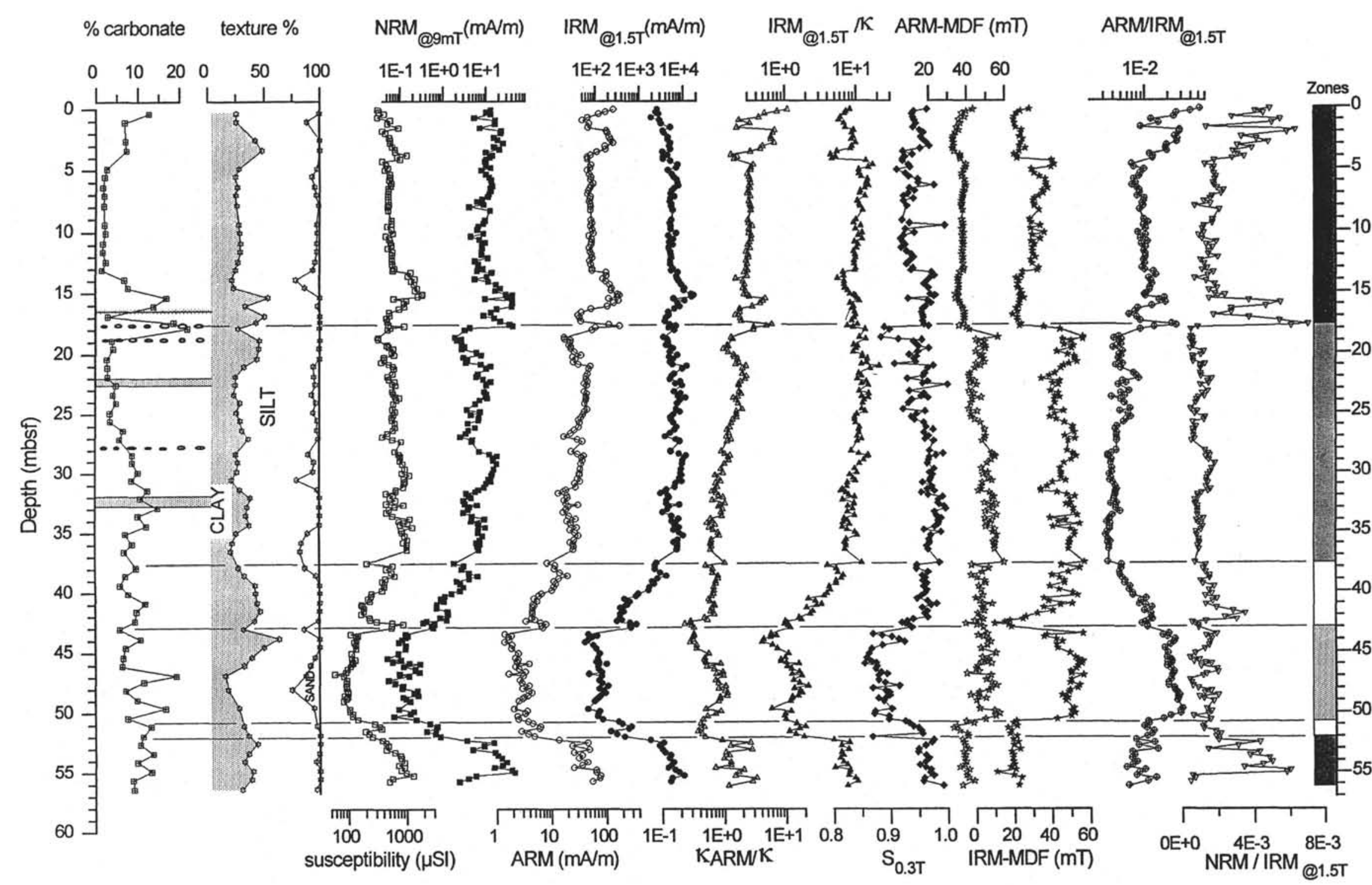

Figure 6. Downhole plot of susceptibility (open squares), NRM (solid squares), ARM (open circles), IRM (solid circles), KARM/K (open triangles), IRM/K (solid triangles), $\mathrm{S}_{03 \mathrm{~T}}$ (rhombi), MDF-ARM (open stars), MDF-IRM (sisT $_{\text {(solid stars), ARM/IRM }}$ (circled plus signs), and NRM umns with modified gray color intensities (see Fig. 3). \%Carbonate is redrawn from Christensen et al. (this volume). Relative percentage of clay, silt, and sand (\%texture) is redrawn from Saito (this volume). Also shown are schematic lithologic features (Shipboard Scientific Party, 1994). Open ellipsoids represent pyrite nodules. Light stippled area =interval with small sandy layers. 
low intensity Zone IV. In the following, relative differences between and among the four magnetic Zones will be discussed.

\section{Zone I}

Zone I is characterized by a bimodal assemblage of coarse magnetite (lowest MDF-IRM, $B_{\text {cr }}$; Fig. 6), which is associated with a relatively enhanced contribution of fine-grained magnetite with coercivities $\geq 20 \mathrm{mT}$ (highest ARM intensity, whereas the MDF-ARM remains almost constant throughout Zones I-IV). Prominent peaks in ARM intensity in Zone I reflect higher relative contributions of finegrained magnetite. A general concetration peak of the ferrimagnetic minerals can be excluded because the maxima are neither monitored in IRM intensity nor susceptibility (Fig. 6). The maxima in the ratios $\mathrm{ARM}_{\mathrm{IRM}} \mathrm{I}_{\mathrm{1.5T}}$ (Fig. 6) and $\kappa \mathrm{ARM} / \kappa$ (e.g., King et al., 1982) in Zone I confirm this, whereas the central grain-size tendency is coarsest in Zone I. Such concentrations of fine-grained magnetite in Zone I are marked by two prominent double peaks at the top of the sampled interval within the uppermost strata of the sediment ( $0-4.2 \mathrm{mbs})$ and between 15.8 and $17.8 \mathrm{mbsf}$.

The distinct peak concentrations of fine-grained magnetite are superimposed on the overall relatively coarsest grained ferrimagnetic components in the sampled interval. The first peak concentration is recorded right at the sediment/water interface and then gradually decreases with increasing grain size to $1.8 \mathrm{mbsf}$ (ARM decreases by almost an order of magnitude). The increase in ferrimagnetic grain size runs through the unconformity at the Holocene/late Pleistocene boundary at $1.43 \mathrm{mbsf}$ (Holocene/Oxygen Isotope Stage 5.5; Christensen et al., this volume). At $1.8 \mathrm{mbsf}$ the second fine-grained ferrimagnetic maximum subdivides the sediments with an abrupt shift to higher concentrations (ARM-related parameters in Fig. 6). Concentrations remain continuously high to about $2.8 \mathrm{mbsf}$. Like the first maximum, this concentration of fine-grained magnetite is then gradually lost toward the bottom of this section at 4.2 mbsf. Christensen et al. (this volume) pick the top of Oxygen Isotope Stage 6 at $2.59 \mathrm{mbsf}$, that is, fairly close to the second onset of a loss of fine-grained magnetite at about 2.8 mbsf.

$\mathrm{CaCO}_{3}$ between 15.8 and $17.8 \mathrm{mbsf}$ (Zone I/Zone II boundary) yields a characteristic double peak, which parallels the second set of peak concentrations of fine-grained magnetite. The latter maximum is further correlative with a prominent layer of pyrite nodules, which marks the magnetic Zone I/Zone II boundary. This strongly suggests that the ferrimagnetic component at this point is not detrital in terms of a dilution of the magnetic mineral concentration by a higher nonmagnetic concentration (e.g., Kent, 1982; Robinson, 1986).

$\kappa \mathrm{ARM} / \kappa$ parallels the general downsection trends of ARM/ $\operatorname{IRM}_{\circledast 1.5 \mathrm{~T}}$ and is mainly driven by the peak concentrations of finegrained magnetite. A second diagenetic front is suggested by the onset of generally decreasing $\kappa A R M / \kappa$, which starts at the sediment/water interface and continues downsection to the top of magnetic Zone IV at $42.6 \mathrm{mbsf}$. Since this decrease in $\kappa A R M / \kappa$ is neither recorded in $\mathrm{ARM} / \mathrm{IRM} \mathrm{\Theta}_{\oplus .5 \mathrm{~T}}$ nor in $\mathrm{IRM}_{\Theta 1.5 \mathrm{~T}} / \kappa$, a constantly increasing downhole paramagnetic : ferrimagnetic ratio is suggested (i.e., a relative loss of the finer grained magnetite).

The abrupt offsets in Zone I rock-magnetic properties are in general correlative with changes in sediment texture (Saito, this volume), that is, either a relative increase (decrease) of the clay content or the sand fraction right at the point of dramatic changes in either concentration or grain size of the magnetic minerals. This relationship does not necessarily imply a general downhole correlation of sediment texture and rock-magnetic properties. More likely, the relationship reflects the initiation or termination of a downhole modulation of the magnetic signal by magnetite dissolution or authigenesis.

\section{Zone II}

A distinct offset in magnetic properties is obvious with respect to the bordering Zones I and III at 17.8 and $37.8 \mathrm{mbsf}$. The central grainsize tendency reflects finer magnetite compared to Zone I (Figs. 3, 6). ARM/IRM ratios decrease slightly from the top to the bottom of Zone II. These lowest ARM/IRM ratios reflect a decrease of the ARM enhanced ferrimagnetic fraction (20-50-mT coercivities) relative to the total grain-size distribution. Since this effect is enhanced in $\kappa A R M / \kappa$ (continuing the trend from Zone I; Fig. 6) and is absent in the IRM/א ratio, an additional downhole increase of paramagnetic material vs. finer grained magnetite is indicated (i.e., a loss of finer magnetite). Relatively low $\mathrm{S}_{0.3 \mathrm{~T}}$ values (about 0.9 ) indicate a higher ferrimagnetic : antiferromagnetic ratio from the top of Zone II to $18.9 \mathrm{mbsf}$.

Neither the rock-magnetic properties nor the lithology vary significantly within Zone II. Despite, both the natural and artificial intensities (Fig. 6) as well as the grain size of the ferrimagnetic minerals (MDF-IRM, $\mathrm{B}_{\mathrm{cr}}$ ) show distinct offsets that sensitively record distinct sediment packages and/or diagenetic changes in the sediment column. Such abrupt changes in the rock-magnetic properties subdivide Zone II on a scale of several meters. The magnetic signal mimics the general meter-scale variation in the clay contents in this interval (\%texture; Fig. 6). In contrast to magnetic Zone I, those intervals with higher susceptibility are roughly correlative with sediments with decreased clay contents.

The dramatic and abrupt shift in the magnetomineralogy that defines the Zone I/Zone II boundary is not associated with a comparable change in the general sediment composition, although there is a slight increase in the clay contents at about this point. However, the increase in the concentration of a high coercivity mineral at the top of Zone II (17.8-18.9 mbsf) occurs between two prominent layers of pyrite nodules at the top and at the bottom of this interval (Fig. 6). Additionally, the relative contribution of fine ferrimagnetic grains decreases constantly downward in this small section from the top of Zone II to the layer of pyrite nodules at $18.9 \mathrm{mbsf}$.

Variations in magnetite grain size are associated with two couplets of small-scale sandy layers at 22 and $31.8 \mathrm{mbsf}$ (Fig. 6, schematized as stippled area in double line overlaid on the carbonate curve). Both sand-layer couplets mark the endpoints of a coarsening downward of the magnetic mineralogy, which starts some meters above the sand intervals. The onset of the respective trends is associated with a section of intensified bioturbation at $19.3 \mathrm{mbsf}$ close to the pyrite nodules at $18.9 \mathrm{mbsf}$ and a third layer of pyrite nodules at $27.3 \mathrm{mbsf}$. Thus, the change of the magnetic mineralogy is not restricted to the sandy layers and rather infers a diagenetic cause of these trends.

\section{Zone III}

The intensities of natural and laboratory induced magnetizations in Zone III are transitional to the bordering Zones II and IV. Although the total ferrimagnetic concentration sharply decreases in the section on top of Zone IV (Fig. 6), the relative concentration of magnetite in the $20-50-\mathrm{mT}$ coercivity range increases again (AF demagnetization, ARM/IRM $\mathrm{\Theta IITT}_{\text {) }}$. Additionally, the overall influence of paramagnetic material in relation to the coarser ferrimagnetic minerals sharply increases downhole (constant $\kappa A R M / \kappa$, decrease in IRM/ $/$ ). $\mathrm{S}_{0.3 \mathrm{~T}}$ indicates a constant downsection ferrimagnetic to antiferromagnetic ratio, but is abruptly offset to lower values compared to Zone II.

The transitional rock-magnetic properties of magnetic Zone III are correlative with an increase in \%clay (decrease of \%sand). A diatom-rich interval in between 42 and $42.5 \mathrm{mbsf}$ (Shipboard Scientific Party, 1994a, 1994b) at the transition from Zone III to Zone IV is associated with a dramatic decrease in MDF-IRM and $\mathrm{B}_{\mathrm{cr}}$ as well as in 
$\kappa \mathrm{ARM} / \kappa$ and $\mathrm{ARM} / \mathrm{IRM} \mathrm{\Theta I.5T}$ to $43 \mathrm{mbsf}$. This indicates a sharp relative increase of coarse-grained ferrimagnetic minerals in this interval, combined with a slightly higher contribution of antiferromagnetic hematite $\left(\mathrm{S}_{0.3 \mathrm{~T}}\right)$. In the small section of Zone III below Zone IV $(50.92$ $52.01 \mathrm{mbsf}$ ) the respective inverse trends are recorded. The transition from Zone III to the lower part of magnetic Zone I at $52 \mathrm{mbsf}$ is again associated with an abrupt steplike shift in the rock-magnetic properties, back to the magnetomineralogy described for Zone I.

\section{Zone IV}

The ferrimagnetic concentration in Zone IV is consistently very low (Fig. 6), whereas the relative contribution of magnetite in the 20$50-\mathrm{mT}$ coercivity range is highest in this section (highest ARM/ IRM). This relative enhancement of the finer ferrimagnetic fraction is caused by a lack of the low coercivity (coarsest) magnetite component (AF demagnetization of IRM, ARM). The relative contribution of paramagnetic minerals to susceptibility is highest in Zone IV. This is confirmed by the ratio of high-field susceptibility $(\chi \mathrm{hf})$ to low-field susceptibility $(\chi)$. Only in Zone IV do paramagnetic minerals dominate susceptibility (e.g., Richter and van der Pluijm, 1994), whereas the remainder of the sampled section is dominated by the ferromagnetic component (Table 2). $\mathrm{S}_{0.3 \mathrm{~T}}$ values have the lowest ferrimagnetic $:$ antiferromagnetic ratio in the profile (i.e., highest hematite concentration, whereas $\mathrm{S}_{0.3 \mathrm{~T}}$ still is $>0.85$ ). The magnetic properties of Zone IV are not correlative with comparable changes in the general lithologic composition of the sediment (Fig. 6). Note, however, that the interval below $43 \mathrm{mbsf}$ is associated with a dramatic increase in the clay contents, which then gradually decreases again to $47 \mathrm{mbsf}$. This interval is correlated with Oxygen Isotope Stage 7 (Christensen et al., this volume), based on foraminiferal and geochemical changes.

\section{Hole 903A}

Compared to Hole 904A the sampled Pleistocene interval at Hole $903 \mathrm{~A}$ is characterized by a coarser assemblage of PSD through SD magnetite of narrow grain-size distribution. IRM-acquisition curves of selected samples indicate magnetite and saturation is achieved at fields below $0.5 \mathrm{~T}$ (no figure). A nearly continuous contribution of a high coercivity mineral is evident $\left(\mathrm{S}_{0.3 \mathrm{~T}}\right.$ about 0.95$)$.

Magnetization intensities at Hole 903A do not exceed one order of magnitude. Remanent coercivities (MDF and $\mathrm{B}_{\mathrm{cr}}$ ) are very uniform downsection. They are comparable to magnetic Zone I at Hole 904A in that the MDF-IRM at Hole 903A is generally distinctly lower (at about $20 \mathrm{mT}$ ) than the MDF-ARM (at about $35 \mathrm{mT}$ ). The overall homogenous magnetic properties at Site 903 are divided into three magnetic subzones: Zone A (0-6.3 mbsf), Zone B (6.4-10.91 mbsf), and Zone C (11-37 mbsf). Notable variations in the rock-magnetic properties are largely restricted to the upper $11 \mathrm{~m}$ of the sampled interval. Differences of the three zones are outlined in the following.

Hole $903 \mathrm{~A}$ samples are characterized by SD grains (Fig. 7). Zone $\mathrm{C}$ is clearly separated from Zones $\mathrm{A}$ and $\mathrm{B}$ by a greater influence from (super)paramagnetic minerals (cf. Fig. 9, inverse relationship of generally low susceptibilities and generally highest laboratory induced remanences). Samples from Zone B have not been highlighted in the plot, but they do account for the lower left corner of the Zone A and $\mathrm{B}$ distribution. These samples indicate an increasing influence of (super)paramagnetic minerals, which is transitional to Zone $\mathrm{C}$. Although $\mathrm{S}_{0.3 \mathrm{~T}}$ in the sampled interval is almost constant, Zone A and Zone B are clearly separated from Zone $\mathrm{C}$ by a wide range of the respective finest (Zone A) and coarsest ferrimagnetic grains (Zone B) relative to Zone C (Fig. 8).

A good general correlation on a meter scale exists for both concentration dependent and independent rock-magnetic parameters (Fig. 9). Major downhole trends in magnetic susceptibility (abrupt increase at $6.3 \mathrm{mbsf}$ ) are driven by superparamagnetic grains. $\kappa$ is in-
Table 2. Percentage of ferromagnetic minerals contributing to susceptibility, Hole 904A.

\begin{tabular}{lcrr}
\hline $\begin{array}{l}\text { Core, section, } \\
\text { interval }(\mathrm{cm})\end{array}$ & $\begin{array}{c}\chi \mathrm{hf} \times 10^{-8} \\
\left(\mathrm{~m}^{3} / \mathrm{kg}\right)\end{array}$ & $\begin{array}{c}\chi \times 10^{-8} \\
\left(\mathrm{~m}^{3} / \mathrm{kg}\right)\end{array}$ & \%Ferro \\
\hline $150-904 \mathrm{~A}-$ & & & \\
$1 \mathrm{H}, 88-100$ & 5.79 & 28.28 & 79.5 \\
$2 \mathrm{H}, 58-60$ & 6.91 & 29.94 & 76.9 \\
$3 \mathrm{H}, 115-117$ & 7.34 & 33.30 & 78.0 \\
$5 \mathrm{H}, 9-11$ & 7.68 & 22.07 & 65.2 \\
$6 \mathrm{H}, 32-34$ & 4.51 & 4.51 & 0.1 \\
\hline
\end{tabular}

Notes: $\chi \mathrm{hf}=$ high-field mass susceptibility, and $\chi=$ mass susceptibility.

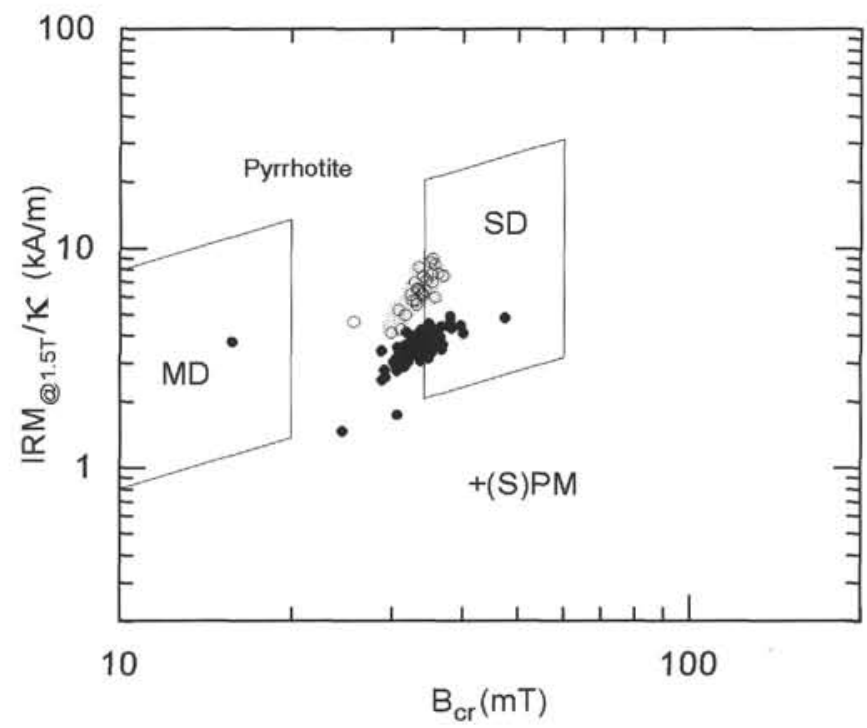

Figure 7. Comparison of Hole 903A rock-magnetic properties with grain-size classification following Bradshaw and Thompson (1985). Open circles = Zones $\mathrm{A}$ and $\mathrm{B}$, and solid circles $=\mathrm{Z}$ one $\mathrm{C} . \mathrm{MD}=$ multidomain magnetite, $\mathrm{SD}$ = single-domain magnetite, and $(\mathrm{S}) \mathrm{PM}=$ (super)paramagnetic minerals.

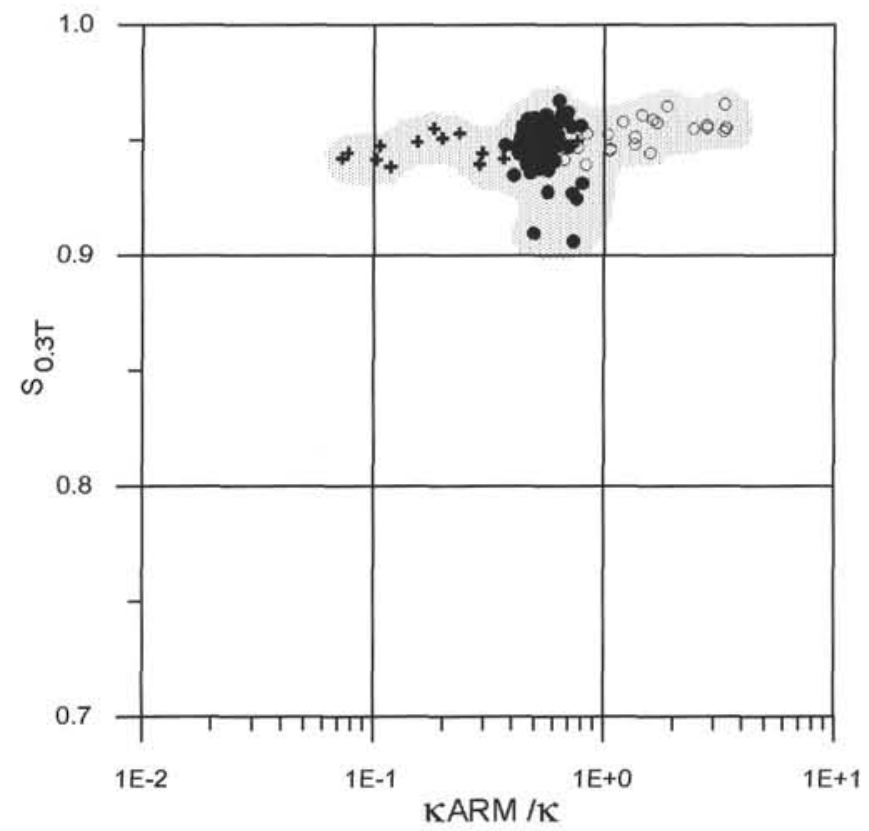

Figure 8. Semilogarithmic scatter plot of $\mathrm{S}_{0,3 \mathrm{~T}}$ vs. $\mathrm{KARM} / \kappa$ for Hole $903 \mathrm{~A}$. Zone $\mathrm{A}=$ open circles, $\mathrm{Z}$ one $\mathrm{B}=$ plus signs, and Zone $\mathrm{C}=$ solid circles. 
$\%$ carbonate texture \% $\quad \mathrm{NRM}_{@ 9 \mathrm{mT}}(\mathrm{mA} / \mathrm{m}) \quad \mathrm{IRM}_{@ 1.5 T}(\mathrm{~mA} / \mathrm{m}) \quad \mathrm{IRM}_{@ 1.5 T} / \mathrm{K} \quad$ ARM-MDF (mT) $\quad$ ARM / IRM @1.5T

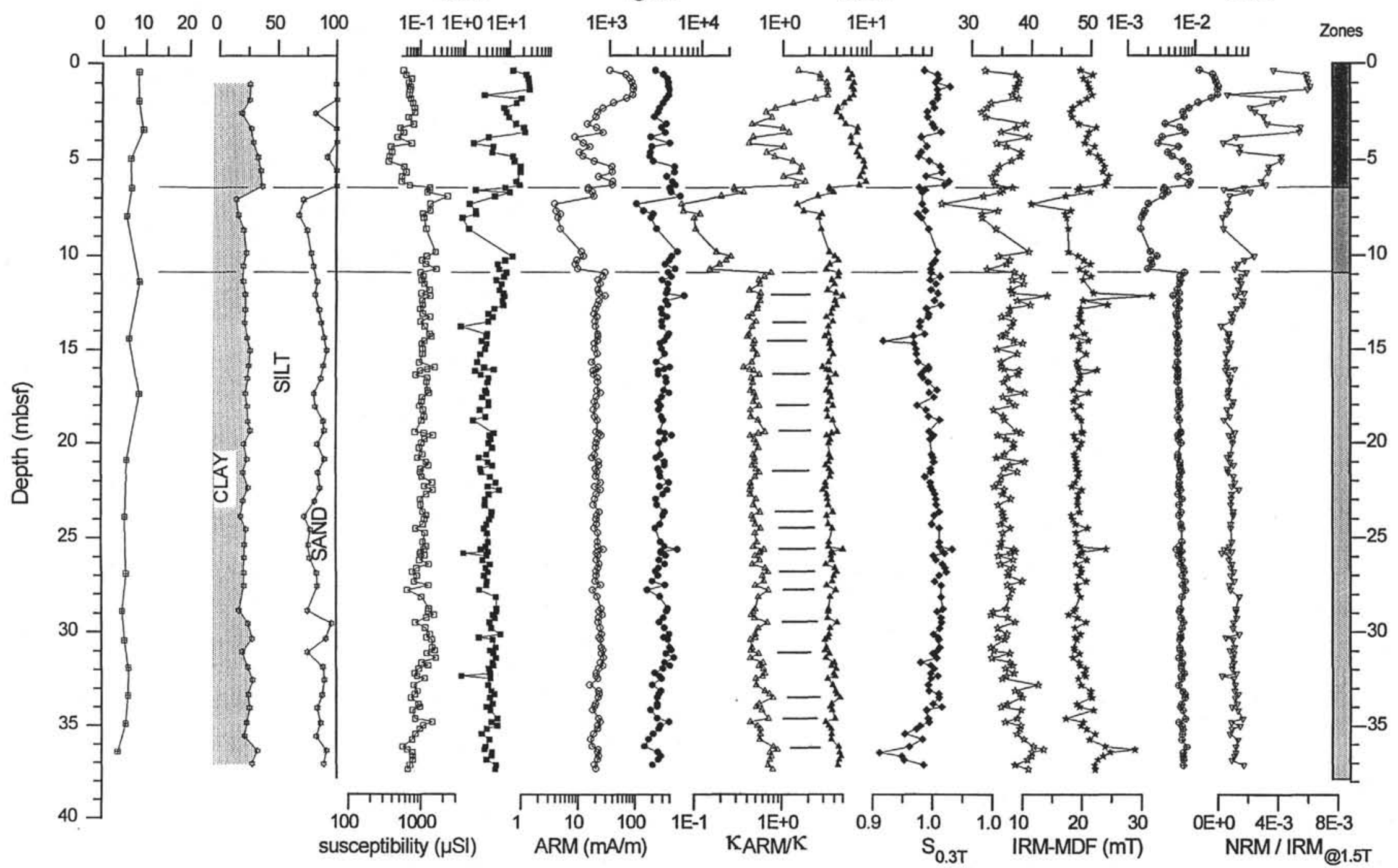

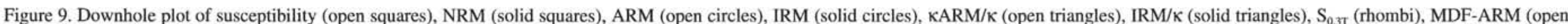

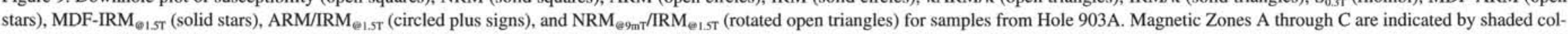
umns with decreasing gray color intensities (dark gray $=$ Zone $\mathrm{A}$, middle gray $=$ Zone $\mathrm{B}$, and light gray = Zone $\mathrm{C}$ ). \% Carbonate is redrawn from Christensen et al. (this volume). Relative percentage of clay, silt, and sand (\%texture) is redrawn from Saito (this volume). Also shown are schematic lithologic features (Shipboard Scientific Party, 1994). Light stippled horizontal lines $=$ small-scale sand layers. 
versely correlated with both the paramagnetic clay contents (\%texture; Fig. 9) and the concentration of ferrimagnetic minerals. A dramatic increase in the concentration of paramagnetic minerals other than clay minerals with high intrinsic susceptibilities (e.g., hornblende) is not known in the interval below $6.3 \mathrm{mbsf}$, and would not adequately explain the susceptibility increase. Details are discussed for the respective Zones A through $\mathrm{C}$.

\section{Zone A}

Zone A is characterized by lowest susceptibilities and highest relative contribution of fine-grained magnetite in this interval (highest ARM intensity and highest ratios of ARM related parameters). Rockmagnetic parameters derived from ARM and IRM measurements parallel one another in their general trend on a centimeter scale. There is, however, a remarkable difference within the range of variation. Although ARM decreases within the uppermost 3 mbsf from maximum values $(0.1-1.8 \mathrm{mbs})$ on the order of one magnitude to average values of about $200 \mathrm{~mA} / \mathrm{m}$ for the remainder of the section, the intensity of IRM remains in the average magnetization of the whole sampled interval (about $4 \mathrm{~A} / \mathrm{m}$ ). AF-ARM demagnetization curves typically indicate SD magnetite, contrasting the multidomain type AFIRM demagnetization (see Hole 904A description). Highest ARM/ IRM ratios mimic trends in $\kappa A R M / \kappa$ and IRM $/ \kappa$. Higher values of MDF-ARM and MDF-IRM are related to higher magnetization intensities and vice versa. The MDF-IRM values generally increase from the top to the bottom of Zone A, whereas the MDF-ARM between 4.2 mbsf and the bottom of Zone A drop to a relative minimum. Comprehensively, the rock-magnetic behavior indicates that the relative contribution of coarse-grained (MD) magnetite is lowest in Zone A and that in contrast the finer fraction of magnetite (i.e., MDF $>14 \mathrm{mT}$, especially $0.1-1.5 \mathrm{mbsf}$ ) is more prominent than it is in the rest of the profile. The relative contribution of fine-grained magnetite over paramagnetic minerals is enhanced in Zone A compared to Zones B and C. This is most obvious at the top of Zone A. Below 4.2 mbsf the general inverse trends of MDF-ARM (decreasing) and MDF-IRM (increasing) suggest that both coarsest grained and finest grained magnetite are gradually lost toward the bottom of Zone A.

Zone A rock-magnetic properties are subdivided by abrupt, stepwise shifts in either concentration dependent or concentration independent parameters. Steplike changes are only poorly correlative with lithology. Examples are at 1.8,3, and 5 mbsf (Fig. 9). The relative high concentration of fine-grained magnetite starts to decrease at $1.8 \mathrm{mbsf}$. This correlates fairly well with the Holocene/Oxygen Isotope Stage 5 boundary at $1.64 \mathrm{mbsf}$ (see Christensen et al., this volume), at which depths Holocene sediments unconformably overlie late Pleistocene clayey silts. The bottom of magnetic Zone A at 6.3 mbsf precedes a prominent change (Shipboard Scientific Party, 1994a, 1994b) in sediment structure (at $6.45 \mathrm{mbsf}$ ) and lithologic composition (at $6.8 \mathrm{mbsf}$ ) by several centimeters. However, the steplike shift to overall coarser ferrimagnetic minerals (Zones B and C) coincides with the Oxygen Isotope Stage 5/Stage 6 boundary (Christensen et al., this volume). Lowest susceptibilities of Zone A are inversely correlated with the highest clay content in the sampled sediments and the highest concentration of fine-grained ferrimagnetic minerals.

\section{Zone B}

The magnetic properties of Zone B samples (6.4-10.91 mbsf) are separated from Zone $\mathrm{A}$ and Zone $\mathrm{C}$ by abrupt changes in concentration and grain-size distribution of the magnetomineralogy. The latter reflect the dominance of relatively coarse-grained magnetite. The relative contribution of (super-)paramagnetic minerals significantly increases. This is apparent from (1) a steplike decrease of MDF-IRM and an increase of MDF-ARM (AF-demagnetization curves are typ- ically linear, with MDF-ARM greater than MDF-IRM; i.e., SD magnetite tendency after Lowrie and Fuller, 1971); (2) a dramatic decrease of $\kappa A R M / \kappa$ and IRM/ $\kappa$; and (3) a decrease in the ARM/IRM ratio (lowered ARM intensity, constant IRM intensity) at the top of Zone B. A second steplike decrease of concentration dependent and independent parameters indicates the ongoing coarsening (loss of fine-grained magnetic material) of magnetite and the increasing influence of (super)paramagnetic minerals. Minimum values of this change in magnetic mineralogy are encountered at $7.4 \mathrm{mbsf}$. Below this interval another abrupt increase of the MDFs is associated with a gradual increase of magnetization intensities and thus again reflects the increase of fine-grained magnetite and the relatively decreasing influence of (super)paramagnetic grains. The bottom section of Zone $\mathrm{B}$ (between 9.8 and $10.91 \mathrm{mbsf}$ ) is distinguished from Zone $\mathrm{C}$ below by ARM related parameters only, whereas IRM-related parameters are, on average, comparable with those from underlying Zone $\mathrm{C}$. The rock-magnetic properties indicate a steplike increase of relatively coarse magnetite in the bottom interval, whereas the finer fraction remains low.

A dramatic modulation of the magnetic signal is associated with the small section at 7.4 mbsf just below the 7.05-7.2-mbsf interval, which contains two complete 5 -cm gastropods (Shipboard Scientific Party, 1994a). Because of a lack of samples, it is not clear whether the lithologic change at 9 mbsf (back to clayey silts) is correlative with changes in the magnetic mineralogy. The abrupt offset of ARM related parameters at the Zone $\mathrm{B} /$ Zone $\mathrm{C}$ boundary is correlative with a color change below a small section of intensified bioturbation.

\section{Zone $C$}

Zone C (11-37 mbsf) yields an interval of extremely homogenous magnetic properties (Fig. 9). Despite the absence of notable long-term trends in the independent measurements of $\kappa$, IRM, and ARM intensities, the respective parameters mimic each other in general downhole trends on a centimeter scale (i.e., every sample). Thus, the significance of each value is clearly demonstrated and an interpretation of even the smallest variations is justified. A linear regression of $\kappa v s$. respectively ARM and IRM yields a significant correlation only for the latter ( $\kappa$ is linear in IRM with $R=0.6$ ). The poor correlation to ARM is the result of notable shifts in the range of variation, that is, marked differences in the amplitude of change on a sample to sample basis. There is almost no variation in the concentration of the smaller ferrimagnetic components (ARM ranges from 16.2 to $30.4 \mathrm{~mA} / \mathrm{m}$ ), whereas both IRM and $\kappa$ display a relatively wider range (IRM: $2.4-6.5 \mathrm{~A} /$ $\mathrm{m}, \kappa: 561.8-1626 \mu \mathrm{SI}$ ). Differences in the amount of decrease (increase) may thus be used to display modifications of the magnetic signal with respect to relative changes in the contribution of the paramagnetic and ferrimagnetic minerals in a sample (IRM/ $/$ and $\kappa A R M / \kappa)$. Peak values in both IRM/ $/ \kappa$ and $\kappa \mathrm{ARM} / \kappa$ reveal a certain cyclicity on a several meter scale (Fig. 9, marked by horizontal lines between the two curves) displaying relative enhancement of the ferrimagnetic fraction over the paramagnetic components of the macroscopically almost homogenous silty clays in Zone $\mathrm{C}$. Varying grain sizes of the ferrimagnetic components should have little effect on the ARM and IRM in Zone $\mathrm{C}$ because the AF demagnetization of both ARM and IRM results in almost constant MDFs downcore.

Comparison of the higher MDF-ARM (about $40 \mathrm{mT}$ ) and MDFIRM (about $20 \mathrm{mT}$ ) indicates the presence of relatively large amounts of coarse ferrimagnetic grains (see Hole 904A discussion). Peak values of MDF-ARM and MDF-IRM are correlative with small sandy layers present throughout Zone C (barrel sheets; Shipboard Scientific Party, 1994a) and thus indicate a finer ferrimagnetic component associated with the sands. MDF values increase slightly below 28.5 mbsf, coincident with a general, minor decrease in both IRM and $\kappa$. These trends in the rock-magnetic properties are correlative with a color change at $28.5 \mathrm{mbsf}$ as well as slightly increasing clay contents (decreasing sand contents) in this interval (see \%texture in Fig. 9). 


\section{DISCUSSION}

Since sedimentation on the upper slope is potentially influenced by terrigenous material one might expect a contribution by detrital titanomagnetites to the magnetic signal. A comparison of both the IRM and the ARM AF-demagnetization characteristics of the Hole 904A samples with the experimental results from Dankers (1978) does not indicate the presence of this remanent magnetic mineral. Titanomagnetites ( $<5$ through $30-40 \mu \mathrm{m}$ ) display convex-shaped AF-demagnetization curves, in contrast to the investigated samples from Hole 904A. Furthermore, Danker's (1978) data suggest that (coarse) titanomagnetite is more easily magnetized by ARM than magnetite. This does not agree with the ARM magnetization behavior discussed above.

In the largely reducing Pleistocene New Jersey slope sequences, where nonmagnetic pyrite formation is favored (Shipboard Scientific Party, 1994a, 1994b), the possible contribution of the ferrimagnetic iron sulfides greigite $\left(\mathrm{Fe}_{3} \mathrm{~S}_{4}\right)$ and monoclinic pyrrhotite $\left(\mathrm{Fe}_{7} \mathrm{~S}_{8}\right)$ to the remanent magnetizations must be considered. However, the samples analyzed display distinctly lower coercivities $\left(\mathrm{H}_{\mathrm{c}}<23 \mathrm{mT}\right.$; Fig. 2) than has been reported for natural sedimentary greigites $\left(H_{c}=41-57\right.$ $\mathrm{mT}$; Snowball, 1991). In additional, the low IRM/ $\mathrm{\kappa}$ ratios of the samples (Fig. 3) do not match the high ratios generally characteristic for greigite (about $70 \mathrm{kA} / \mathrm{m}$; Snowball and Thompson, 1990). The same criterion (IRM/ $/$ ) can be used to rule out pyrrhotite (Fig. 3).

The high resolution downhole analysis of the two New Jersey slope sites strongly suggests that the magnetic signal of both the Pleistocene sections is a composite of postdepositional dissolution and authigenic growth of fine-grained magnetite, superimposed on the primary detrital magnetic input. I infer that this modulation of the magnetic signal is tied to the series of reductive reactions in the bacterial degradation of organic matter.

\section{The Detrital Magnetic Signal}

The overall coarser central grain-size tendency in the Pleistocene interval of Hole 903A, relative to Hole 904A, located farther downslope, suggests a slightly decreasing grain size of the ferrimagnetic minerals with increasing distance from the coastline. This in turn is in good agreement with a primary clastic influx from coastal rivers, such as the Hudson or Delaware River. The latter are potential point sources for sands and muds deposited on the slope (Shipboard Scientific Party, 1994a, 1994b). Mass transport of sediments downslope might have the same effect of grain-size sorting, but it will potentially smear out a clear signal because of the varying origin of the sediments on the slope. The analysis of directional AMS data shows dominantly northwest-southeast (Hole 903A) and north-south (Hole 904A) oriented magnetic fabrics and indicates a downslope sediment transport consistent with the general slope orientation (Urbat, 1995).

At Sites 903 and 904 an overall finer ferrimagnetic assemblage is associated with the interglacials. At Hole 903A the transition from magnetic Zone A (interglacial Stage 5) to Zones B and C (glacial Stage 6) separates an overall finer ferrimagnetic fraction from the more coarse-grained "glacial" magnetic minerals. The interpretation for Hole 904A is less straightforward, although the well defined Oxygen Isotope Stage 7 ( 904 Zone IV) bears a relatively fine ferrimagnetic fraction compared to most of Stage 6 transported sediments on top.

There is generally no striking correlation of the lithologic parameters available for this study and the rock-magnetic record. However, the abrupt offsets in magnetite grain size, concentration or composition of magnetic minerals are associated with, for example, shortterm increases/decreases in sand or clay contents, $\mathrm{CaCO}_{3}$ changes, or generally glacial/interglacial boundaries (Figs. 6, 9). Thus, major downhole changes in the rock-magnetic record are very likely dominated by the primary detrital input of magnetic material. At Hole $904 \mathrm{~A}$ the offset bound magnetic Zones I through IV suggest that the lithology is a composite of several unconformably deposited sediment packages. This is especially evident in the upper part of Zone I (0-17.8 mbsf) and Zone II. Additional subdivisions of these zones could be based on abrupt shifts in grain size and concentration of the magnetic mineralogy. These changes are of minor extent; however, they cramp thinner sediment packages deposited in separate events, for example, mass flows on the slope. It appears from the almost constant magnetic mineralogy that the source or the pathway of the sediments did not change significantly within glacial Stage 6 , which is most prominent in both sampled intervals from Sites 903 and 904. The described offsets in magnetic mineralogy are distinct, although the absolute changes remain relatively small. The only exceptions to this assumption are the boundaries of Zone B (Site 903) and Zone II (Site 904), which are associated with more dramatic changes of the rock-magnetic properties.

The changes described for the magnetic mineralogy from glacial to interglacial stages are more prominent. For example, Site 904 interglacial Stage 7 (Zone IV, 43-47 mbsf) is comprised of a low concentration of ferrimagnetic minerals, suggesting detrital input was low. In situ benthic foraminifers, a low relative percentage of transported benthic foraminiferal assemblages, and interglacial planktonic foraminifers (Christensen et al., this volume) in this interval corroborate this interpretation of in situ sedimentation. If this assumption is valid than these sedimentary conditions developed already at 50.9 mbsf, that is, the base of Zone IV. The gradual overall increase in the concentration of the ferrimagnetic minerals to $37.8 \mathrm{mbsf}$ (Zone III) with a concomitant decrease in both the importance of paramagnetic minerals and fine-grained magnetite over the coarser fraction, indicates a slow transition to glacial Stage 6. A sharp incision at $43 \mathrm{mbsf}$ with a high short-term input of relatively coarse-grained ferrimagnetic material marks the top of Stage 7. There is no evidence of dramatic magnetite dissolution in this interval, which could have caused the low magnetization, alternatively to the inferred dilution of the signal.

\section{Magnetite Dissolution}

The dissolution of magnetite in the sampled interval at Hole 904A is associated with the finer ferrimagnetic minerals contained in the sediments. This is obvious, since the most prominent (relative) concentration and grain-size changes are related to ARM parameters only. At both Holes 903A and 904A, the uppermost sediment layers are characterized by peak concentrations of fine-grained magnetite, which appears to be superimposed on a relatively coarse-grained ferrimagnetic component. At Hole 904A, the loss of this fine-grained magnetite begins immediately below the water/sediment interface and ends at about the base of the Holocene interval. This indicates magnetite dissolution that is tied to the series of redox reactions in the course of bacterial degradation of organic matter (cf., e.g., Karlin, 1990a, 1990b; Leslie et al., 1990a, 1990b).

Figure 10 shows a certain looping behavior of increasing and decreasing grain sizes within the uppermost 3.56 mbsf containing the two peak concentrations of fine-grained magnetite. To display the grain-size variation of the finer ferrimagnetic minerals in this interval ARM-related parameters were chosen, which are sensitive to grainsize changes (cf. Maher, 1988). A similar looping behavior of first decreasing, than increasing and again decreasing grain size has been reported by Karlin (1990a), and has been attributed to the preferential dissolution of the finest fraction, followed by a grain-size decrease when the coarser grains are finally attacked. At Hole 904A the changing grain sizes result from two separate events, where dissolution does not attack the coarser grains and only the finer magnetite is lost below the respective maximum concentrations. The jump back to finer grain sizes coincides with the hiatus between the Holocene and the enrichment in fine-grained magnetite in interglacial Stage 5.5.

A similar feature of a looping like grain-size change is associated with the second interval ( 15.8 and $17.8 \mathrm{mbsf}$ ) containing two prominent peaks of fine-grained magnetite (Fig. 10). Again this variation 

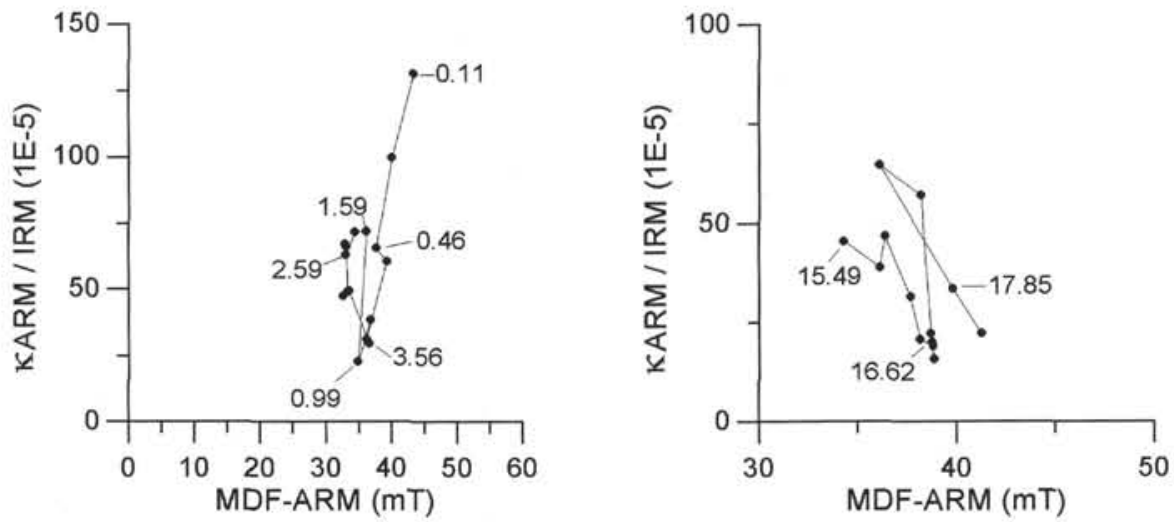

Figure 10. Plot of KARM/IRM ${ }_{\oplus 1.5 T}$ vs. MDF-ARM (following Maher, 1988) for two intervals at Hole 904A. Numbers in plot denote sample depths in mbsf.

reflects the dissolution of the finer ferrimagnetic minerals in short, well-defined intervals. Dissolution proceeds downward from the respective point of maximum magnetite concentration and ends with a lithologic change. The lithologic background in this interval (correlation to layers of pyrite nodules, peak concentration of carbonate, intensified bioturbation), in combination with the rock-magnetic signal, strongly suggests interruptions of the geochemical steady state, preserving repeated thin intervals of magnetite dissolution.

In the upper $38 \mathrm{~m}$ (Zones I and II) at Hole 904A, these separate diagenetic features are overlain by the only obvious diachronous downhole modulation of the magnetic signal. The continuous decrease in the ratio $\kappa A R M / \kappa$ (Fig. 6) indicates the gradual dissolution of the finer ferrimagnetic minerals. This inferred diagenetic alteration of magnetite must then be a second process after the dissolution in well-defined intervals described before. This second process gradually removed some of the finer magnetite, but it did not yet level downhole trends of the magnetic signal in the current sulfate reduction zone.

The topmost layers at Hole 903A (Zones A and B; Fig. 9) are characterized by two sections in which the relative contribution of fine-grained magnetite significantly decreases.

1. Just below the Holocene/late Pleistocene unconformity at 1.8 mbsf, fine-grained magnetite is rapidly lost. This decrease is not associated with a comparable change in the lithologic record and likely reflects the dissolution of the ferrimagnetic mineral.

2. The second dramatic decrease in the relative concentration of fine magnetite is recorded immediately below the Stage 5.5/ Stage 6 boundary (?unconformity) at $6.3 \mathrm{mbsf}$.

Fine-grained magnetite remains low, relative to the overall ferrimagnetic concentration and grain size, throughout Zone B to $11 \mathrm{mbsf}$ and then abruptly increases again (ARM-related parameters in contrast to IRM-related parameters). Since the interglacial to glacial change at $6.3 \mathrm{mbsf}$ is associated with a dramatic overall increase of the grain size of the sediment (Fig. 9), the rock-magnetic properties do in part reflect this lithologic variation by a coarser central grainsize tendency and a drop in the concentration of magnetic minerals. However, neither the lithology nor the general magnetic signal reflects any sharp change at 11 mbsf. The separation of magnetic Zone $\mathrm{B}$ is based on the dramatic decrease in the relative concentration of the fine-grained ferrimagnetic minerals and likely reflects the dissolution of this component between 6.3 and 11 mbsf. If this assumption is valid, a second diagenetic front is required on account of this dissolution of magnetite. Additionally, the poor record of the NRM signal in Zone B can in part be explained by a dissolution of the finer ferrimagnetic carriers of remanence, leaving only the coarse-grained and insufficiently aligned detrital part of the magnetic tape.
Contrasting Hole 904A, diachronous and gradual changes of the rock-magnetic properties are not recorded at Hole 903A. This might be caused by the lower sedimentation rate at Hole 904A in combination with a reduced speed of reductive diagenesis. This might lead to a longer and/or repeated contact of magnetite with the reducing agent at Hole $904 \mathrm{~A}$, be it either $\mathrm{H}_{2} \mathrm{~S}$ or iron-reducing bacteria.

\section{Authigenic Magnetite}

The peak concentrations of fine-grained magnetite in the sampled intervals of both holes are correlative with those intervals of highest NRM/IRM ratios (Figs. 6, 9) and thus indicate highest alignment efficiency of the carriers of the NRM. This coincides with the growth of a chemical remanent magnetization (CRM) in these sections, resulting in a better alignment compared to the otherwise dominating detrital remanent magnetization.

Peak concentration of fine-grained magnetite in the sampled intervals are related to inferred unconformities in the sediment. These high concentrations are most prominent in the Holocene sections of both Sites 903 and 904 . At the latter magnetite starts to dissolve right at the sediment/water interface. Additional well defined maxima are recorded at the Holocene/Stage 5.5 unconformity (Hole 904A) and between 15.8 and $17.8 \mathrm{mbsf}$ at Site 904 . These may reflect trapped magnetite concentrations in terms of an interruption of steady state conditions and will then represent paleoredox markers, in the sense of Karlin (1990a).

\section{CONCLUSIONS}

The primary detrital magnetic signal at Holes $903 \mathrm{~A}$ and $904 \mathrm{~A}$ is overlain by both dissolution as well as an authigenic growth of magnetite, although the former is still dominant. The modulation of the primary signal is restricted to the finer ferrimagnetic fraction, whereas the coarse-grained magnetic material remains relatively unaltered. Both dissolution and authigenic growth of magnetite are dominantly associated with separate meter-scale sections of the sampled intervals and are typically related to the interface of unconformably deposited sediment packages. Detectable rock-magnetic patterns are preserved when nonsteady state conditions developed during diagenesis (sedimentation rate changes). They mimic dissolution/precipitation of magnetite, which has been reported to occur just below the sediment/ water interface (e.g., Leslie et al., 1990a, 1990b); thus, these rockmagnetic patterns likely reflect preserved markers of, for example, fluctuating redox conditions. Evidence of a continuous downhole diagenetic alteration of the magnetic mineralogy is scarce, although present at Hole 904A and thus suggests the alteration of the magnetic signal occurred repeatedly during sediment diagenesis.

The consideration and combined analysis of various rock-magnetic parameters is essential to interpret the sometimes only minor and 
relative changes of the magnetic record that are caused by reductive diagenesis. A successful discrimination of detrital and postdepositional components of the magnetic signal using standard rock-magnetic parameters is demonstrated. The grain-size selectivity of the applied ARM-acquisition process can be used to interpret relative grain size and/or concentration changes of the finer ferrimagnetic fraction, and thus is helpful to extend the analysis of the central grain-size tendency alone. Downhole changes of the magnetic signal will vary as a function of a variety of sedimentary processes and thus only an individual interpretation of the obtained rock-magnetic data seems appropriate for each respective location (also see Urbat, 1995).

\section{ACKNOWLEDGMENTS}

I thank Dirk Dörrenberg and Sophie Wolf, who made most of the measurements in Köln, and Jan Reinders for fruitful considerations of the manuscript. Carl Richter provided the $\chi$ hf data and I thank him and an anonymous reviewer for reviews. I am indebted to the participants of Leg 150 for their dedicated assistance at the sampling table. Beth Christensen improved the English of the first draft. This work was funded by the Deutsche Forschungsgemeinschaft (DFG Kr 685$11)$.

\section{REFERENCES}

Anderson, N.J., and Rippey, B., 1988. Diagenesis of magnetic minerals in the recent sediments of an eutrophic lake. Limnol. Oceanogr., 33:14761492.

Bailey, M.E., and Dunlop, D.J., 1983. Alternating field characteristics of pseudo-single-domain $(2-14 \mu \mathrm{m})$ and multidomain magnetite. Earth Planet. Sci. Lett., 63:335-352.

Bazylinski, D.A., Heywood, B.R., Mann, S., and Frankel, R.B., 1993. $\mathrm{Fe}_{3} \mathrm{O}_{4}$ and $\mathrm{Fe}_{3} \mathrm{~S}_{4}$ in a bacterium. Nature, 366:218.

Bloemendal, J., and deMenocal, P., 1989. Evidence for a change in the periodicity of tropical climate cycles at $2.4 \mathrm{Myr}$ from whole-core magnetic susceptibility measurements. Nature, 342:897-900.

Bloemendal, J., King, J.W., Hall, F.R., and Doh, S.-J., 1992. Rock magnetism of late Neogene and Pleistocene deep-sea sediments: relationship to sediment source, diagenetic processes, and sediment lithology. J. Geophys. Res., 97:4361-4375.

Bloemendal, J., King, J.W., Hunt, A., deMenocal, P.B., and Hayashida, A., 1993. Origin of the sedimentary magnetic record at Ocean Drilling Program sites on the Owen Ridge, western Arabian Sea. J. Geophys. Res., 98:4199-4219.

Bloemendal, J., Lamb, B., and King, J., 1988. Paleoenvironmental implications of rock-magnetic properties of late Quaternary sediment cores from the eastern equatorial Atlantic. Paleoceanography, 3:61-87.

Bradshaw, R.H.W., and Thompson, R., 1985. The use of magnetic measurements to investigate the mineralogy of some Icelandic lake sediments and to study catchment processes. Boreas, 14:203-215.

Canfield, D.E., and Berner, R.A., 1987. Dissolution and pyritization of magnetite in anoxic marine sediments. Geochim. Cosmochim. Acta, 51:645659.

Chave, A.D., and Denham, C.R., 1979. Climatic changes, magnetic intensity variations and fluctuations of the eccentricity of the earth's orbit during the past $2,000,000$ years and a mechanism which may be responsible for the relationship: a discussion. Earth Planet. Sci. Lett., 44:150-152.

Dankers, P.H.M., 1978. Magnetic properties of dispersed natural iron-oxides of known grain-size [Ph.D. thesis]. Univ. of Utrecht.

deMenocal, P., Bloemendal, J., and King, J., 1991. A rock-magnetic record of monsoonal dust deposition to the Arabian Sea: evidence for a shift in the mode of deposition at $2.4 \mathrm{Ma}$. In Prell, W.L., Niitsuma, N., et al., Proc. ODP, Sci. Results, 117: College Station, TX (Ocean Drilling Program), 389-407.

Froelich, P.N., Klinkhammer, G.P., Bender, M.L., Luedtke, N.A., Heath, G.R., Cullen, D., Dauphin, P., Hammond, D., Hartman, B., and Maynard, V., 1979. Early oxidation of organic matter in pelagic sediments of the eastern equatorial Atlantic: suboxic diagenesis. Geochim. Cosmochim. Acta, 43:1075-1090.
Gorree, W.S., and Fuller, M.D., 1976. Magnetometers using r.f.-driven squids and their application in rock magnetism and paleomagnetism. Rev. Geophys. Space Phys., 14:591-608.

Heider, F., Dunlop, D.J., and Sugiura, N., 1987. Magnetic properties of hydrothermally recrystallized magnetite crystals. Science, 236:12871290.

Jelinek, V., 1977. The statistical theory of measuring anisotropy of magnetic susceptibility of rocks and its application. Brno, Geofyzika, 1-88.

Karlin, R., 1990a. Magnetic diagenesis in marine sediments from the Oregon continental margin. J. Geophys. Res., 95:4405-4419.

, 1990b. Magnetite mineral diagenesis in suboxic sediments at Bettis Site W-N, NE Pacific Ocean. J. Geophys. Res., 95:4421-4436.

Karlin, R., and Levi, S., 1983. Diagenesis of magnetic minerals in recent hemipelagic sediments. Nature, 303:327-330.

1985. Geochemical and sedimentological control of the magnetic properties of hemipelagic sediments. J. Geophys. Res., 90:10373-10392.

Kent, D.V., 1982. Apparent correlation of paleomagnetic intensity and climatic records in deep-sea sediments. Nature, 299:538-539.

King, J.W., Banerjee, S.K., Marvin, J., and Özdemir, Ö., 1982. A comparison of different magnetic methods for determining the relative grain size of magnetite in natural materials: some results from lake sediments. Earth Planet. Sci. Lett., 59:404-419.

Leslie, B.W., Hammond, D.E., Berelson, W.M., and Lund, S.P., 1990a. Diagenesis in anoxic sediments from the California continental borderland and its influence on iron, sulfur, and magnetite behavior. J. Geophys. Res., 95:4453-4470.

Leslie, B.W., Lund, S.P., and Hammond, D.E., 1990b. Rock magnetic evidence for the dissolution and authigenic growth of magnetic minerals within anoxic marine sediments of the California Continental Borderland. J. Geophys. Res., 95:4437-4452.

Lovley, D., and Phillips, E.J.P., 1988. Novel mode of microbial energy metabolism: organic carbon oxidation coupled to dissimilatory reduction of iron or manganese. Appl. Environ. Microbiol., 54:1472-1480.

Lowrie, W., and Fuller, M., 1971. On the alternating field demagnetization characteristics of multidomain thermoremanent magnetization in magnetite. J. Geophys. Res., 76:6339-6349.

Maher, B.A., 1988. Magnetic properties of some synthetic sub-micron magnetites. Geophys. J. R. Astron. Soc., 94:83-96.

Maher, B.A., and Taylor, R.M., 1988. Formation of ultrafine-grained magnetite in soils. Nature, 336:368-370.

Mann, S., Sparks, N.H.C., Frankel, R.B., Bazylinski, D.A., and Jannack, H.W., 1990. Biomineralization of ferrimagnetic greigite $\left(\mathrm{Fe}_{3} \mathrm{~S}_{4}\right)$ and iron pyrite $\left(\mathrm{FeS}_{2}\right)$ in a magnetotactic bacterium. Nature, 343:258-261.

Mountain, G.S., Miller, K.G., Blum, P., et al., 1994. Proc. ODP, Init. Repts., 150: College Station, TX (Ocean Drilling Program).

Musgrave, R.J., Delaney, M.L., Stax, R., and Tarduno, J.A., 1993. Magnetic diagenesis, organic input, interstitial water chemistry, and paleomagnetic record of the carbonate sequence on the Ontong Java Plateau. In Berger, W.H., Kroenke, L.W., Mayer, L.A., et al., Proc. ODP, Sci. Results, 130: College Station, TX (Ocean Drilling Program), 527-546.

Oldfield, F., 1992. The source of fine grained "magnetite" in sediments. Holocene, 2:180-182

Oldfield, F.I., Darnley, I., Yates, G., France, D.E., and Hilton, J., 1992. Storage diagenesis versus sulphide authigenesis: possible implications in environmental magnetism. J. Palaeoclimatol., 7:179-189.

Petersen, P., von Dobeneck, T., and Vali, H., 1986. Fossil bacterial magnetite in deep-sea sediments from the South Atlantic Ocean. Nature, 320:611615

Reynolds, R.L., Tuttle, M.L., Rice, C.A., Fishman, N.S., Karachewski, J.A., and Sherman, D.M., 1994. Magnetization and geochemistry of greigitebearing Cretaceous strata, North Slope Basin, Alaska. Am. J. Sci. 294:485-528.

Richter, C., and van der Pluijm, B.A., 1994. Separation of paramagnetic and ferrimagnetic susceptibilities using low temperature magnetic susceptibilities and comparison with high field methods. Phys. Earth Planet. Inter., 82:113-123.

Roberts, A.P., and Turner, G.M., 1993. Diagenetic formation of ferrimagnetic iron sulphide minerals in rapidly deposited marine sediments, New Zealand. Earth Planet. Sci. Lett., 115:257-273.

Roberts, A.P., Verosub, K.L., and Negrini, R.M., 1994. Middle/Late Pleistocene relative palaeointensity of the geomagnetic field from lacustrine sediments, Lake Chewaucan, western United States. Geophys. J. Int. 118:101-110. 
Robinson, S.G., 1986. The late Pleistocene paleoclimatic record of North Atlantic deep-sea sediments revealed by mineral-magnetic measurements. Phys. Earth Planet. Inter., 42:22-47.

Schinzel, U., Dahmke, A., and Schulz, H.D., 1993. Reaktionen von Eisen(III)-Oxidhydraten während der Frühdiagenese in marinen Sedimenten: Experimentelle Untersuchungen. Z. Dtsch. Geol. Ges., 144:224247.

Shackleton, N.J., Backman, J., Zimmerman, H., Kent, D.V., Hall, M.A., Roberts, D.G., Schnitker, D., Baldauf, J.G., Desprairies, A., Homrighausen, R., Huddlestun, P., Keene, J.B., Kaltenback, A.J., Krumsiek, K.A.O., Morton, A.C., Murray, J.W., and Westberg-Smith, J., 1984. Oxygen isotope calibration of the onset of ice-rafting and history of glaciation in the North Atlantic region. Nature, 307:620-623.

Shipboard Scientific Party, 1994a. Site 903. In Mountain, G.S., Miller, K.G., Blum, P., et al., Proc. ODP, Init. Repts., 150: College Station, TX (Ocean Drilling Program), 129-205.

, 1994b. Site 904. In Mountain, G.S., Miller, K.G., Blum, P., et al., Proc. ODP, Init. Repts., 150: College Station, TX (Ocean Drilling Program), 207-253.

Snowball, I., 1991. Magnetic hysteresis properties of greigite $\left(\mathrm{Fe}_{3} \mathrm{~S}_{4}\right)$ and a new occurence in Holocene sediments from Swedish Lappland. Phys. Earth Planet. Int., 68:32-40.

Snowball, I., and Thompson, R., 1990. A stable chemical remanence in Holocene sediments. J. Geophys, Res., 95:4471-4479.

Stolz, J.F., Chang, S., and Kirschvink, J.L., 1986. Magnetotactic bacteria and single-domain magnetite in hemipelagic sediments. Nature, 321:849851 .

Stolz, J.F., Lovley, D.R., and Haggerty, S.E., 1990. Biogenic magnetite and the magnetization of sediments. J. Geophys. Res., 95:4355-4361.
Tauxe, L., and Shackleton, N.J., 1994. Relative palaeointensity records from the Ontong-Java Plateau. Geophys. J. Int., 117:769-782.

Thouveny, N., de Beaulieu, J.-L., Bonifay, E., Creer, K.M., Guiot, J., Icole, M., Johnsen, S., Jouzel, J., Reille, M., Williams, T., and Williamson, D., 1994. Climate variations in Europe over the past $140 \mathrm{kyr}$ deduced from rock magnetism. Nature, 371:503-506.

Urbat, M., 1995. Rock magnetic properties of Pleistocene marine sediments of the U.S. middle Atlantic margin and the Japan Sea: case studies on the diagenesis and environmental changes (Ocean Drilling Program Sites 903, 904 and 798) [Ph.D. dissert.]. Univ. of Cologne.

Vali, H., and Kirchvink, J.L., 1989. Magnetofossil dissolution in a paleomagnetically unstable deep-sea sediment. Nature, 339:203-206.

van Hoof, A.A.M., van Os, B.J.H., Rademakers, J.P., Langereis, C.G., and de Lange, G.J., 1992. A paleomagnetic and geochemical record of the upper Cochiti reversal and two subsequent precessional cycles from southern Sicily (Italy). Earth Planet. Sci. Lett., 117:246-255.

van Os, B.J.H., 1994. Primary and diagenetic signals in Mediterranean Sapropels and North Atlantic turbidites: origin and fate of trace metals and paleo-proxies [Ph.D. dissert.]. Rijksuniversiteit te Utrecht, Geologica Ultraiectina.

Verosub, K.L., and Roberts, A.P., 1995. Environmental magnetism: past, present, and future. J. Geophys. Res., 100:2175-2192.

Yu, L., and Oldfield, F., 1989. A multivariate mixing model for identifying sediment source from magnetic measurements. Quat. Res., 32:168-181.

Date of initial receipt: 10 March 1995

Date of acceptance: 8 February 1996

Ms 150SR-025 